\title{
The Effect of Alkyl Substituent Length on Receptor Properties of Dithiaaza-crown - Hemicyanine Monolayers
}

\author{
A. V. Shokurov, ${ }^{a}$ A. V. Alexandrova, ${ }^{a}{ }^{a b}$ E. V. Lukovskaya ${ }_{1}{ }^{c}$ V. V. Arslanov, ${ }^{a}$ \\ and S. L. Selektor ${ }^{\mathrm{Q}}$
}

Dedicated to Academician Aslan Yu. Tsivadze on the occasion of his birthday

\begin{abstract}
${ }^{a}$ A.N. Frumkin Institute of Physical Chemistry and Electrochemistry of Russian Academy of Sciences, 119071 Moscow, Russia

${ }^{\mathrm{b}}$ D.I. Mendeleev University of Chemical Technology of Russia, 125047 Moscow, Russia

${ }^{c}$ M.V. Lomonosov Moscow State University, Chemistry Department, 119991 Moscow, Russia

${ }^{\circledR}$ Corresponding authorE-mail: sofs@list.ru
\end{abstract}

\begin{abstract}
Planar supramolecular systems based on Langmuir monolayers of chromoionophores are widely used for sensor applications, and crown ether ionophoric groups are intensively studied. However, almost no attention is devoted to investigation of effect of alkyl moieties onto receptor properties of such systems. In the present work, we carry out a comparative study of Langmuir monolayers of three alkylated dithiaaza-crown substituted hemicyanine chromoionophores differing only in number of carbon atoms $(12,16,21)$ in the hydrophobic alkyl substituent. A dependence of receptor properties of the studied monolayers on the length of alkyl chain is revealed. It is shown that the efficiency of mercury cations binding by both liquid-expanded and compressed monolayer of dithiaaza-crown substituted hemicyanine dyes formed on pure water subphase is identical for all three compounds with various length of alkyl chain substituent due to the key role of the interactions between chromoionophore fragments of neighboring molecules at the interface. Degree of system sensitivity enhancement due to barium cation-induced preorganization increases with increase of number of carbon atoms in the alkyl chain.
\end{abstract}

Keywords: Hemicyanines, Langmuir monolayers, chromoionophores, alkyl chain length, spectroscopy, sensors.

\section{Влияние Алины алкильных заместителей на рецепторные свойства монослоев Аитиазаазакраун-гемицианинов}

\author{
А. В. Шокуров, ${ }^{a}$ A. В. Александрова, ${ }^{\text {ab }}$ E. В. Ауковская, ${ }^{c}$ B. В. Арсланов, ${ }^{a}$ \\ C. А. Селектор ${ }^{\mathrm{a}}$
}

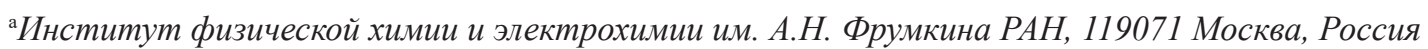

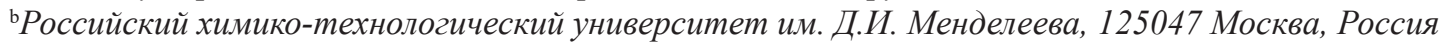
${ }^{\mathrm{c}}$ Московский государственный университет им. М.В. Ломоносова, Химический факультет, 119991 Москва, Россия

@E-mail: sofs@list.ru

Планарные супрамолекулярные системы на основе монослоёв Ленгмюра различных хромоионофоров находят широкое применение в сенсорике, при этом особое внимание привлекают краун-эфирные ионофорныле группь. Однако влияние алкильных заместителей на рецепторные свойства таких систем остаётся практически не исследованным. В настоящей работе проведено сравнительное исследование ленгмюровских монослоев трех алкилированных дитиаазакраун-замещенных гемицианиновых хромоионофоров, отличающихся только числом атомов углерода $(12,16,21)$ в гидрофобном алкильном заместителе. Выявлена зависимость рецепторных свойств исследуемых монослоев от длины алкильной ичепи. Показано, что эффективность связывания катионов ртути монослоями дитиаазакраун-замещенных гемицианиновых красителей, сформированных на поверхности деионизированной воды, как в жидко-расширенном, так и в сжатом состоянии, одинакова 
для всех трех соединений с различной длиной алкильного заместителя из-за определяющей роли взаимодействий между хромоионофорными фрагментами соседних молекул на поверхности раздела. Степень повымения чувствительности системы за счет предорганизации монослоя катионами бария растёт с увеличением числа атомов углерода в алкильной ичепи.

Ключевые слова: Гемицианины, монослои Ленгмюра, хромоионофоры, длина алкильной цепи, спектроскопия, сенсорика.

\section{Introduction}

Currently, sensorics is one of the most promising applications for receptor abilities of macroheterocyclic compounds. ${ }^{[1-4]}$ From this standpoint, crown ether substituted fluoro- and chromophores capable of significant changes of photophysical properties upon selective binding of cations are of special interest. ${ }^{[-11]}$ Modification of the crown ether cycle allows achieving high selectivity and binding constants for biologically and environmentally important metal ions. For example, replacement of one or two oxygen atoms in this cycle by sulfur ones can lead to higher affinity for mercury and copper cations. ${ }^{[12-18]}$ Moreover, simultaneous inclusion of nitrogen atom into the crown-substituent of a coloured molecule as a part of both ionophoric and chromophoric moieties is an easy way to impart the chromoionophoric power to the dye molecule and obtain a spectral response to metal cation binding since their interaction with the nitrogen atom will reduce the overall chromophore conjugation and thus change the photophysical properties of the system. ${ }^{[5-11,19-23]}$ In this regard, aza-crown substituted hemicyanines represent one of the most promising compounds for sensory applications due to the combination of hemicyanine spectral properties (absorbance and fluorescence in visible range), crown ether receptor ability and ease of chemical modification..$^{[5,12,17,24-32]}$

However, most studies concerning the sensory properties of such crown-substituted hemicyanines were done in solution. At the same time, exploitation of the receptor properties of such compounds requires their immobilization onto the surface of the operational element of the sensor. One of the most efficient methods to achieve this is LangmuirBlodgett technique, which allows formation of ultrathin organized films on almost any type of substrates..$^{[7,20,33-39]}$ One of the principal chemical modifications of the hydrophilic hemicyanine molecules needed to use this technique is addition of hydrophobic alkyl chains to attain amphiphility in order to make the molecule surface active. However, the effect of the length of such substituent on the sensory properties of different compounds remains absolutely unstudied.

Thus, the main aim of the present work is comparative study of the structure formation processes in monolayers of amphiphilic chromoionophores based on one crowncontaining hemicyanine dye with hydrophobic alkyl chain substituents of different length and discovering the effect of alkyl chain length on their ability to form complexes with complementary mercury cations at air/ water interface.

\section{Experimental}

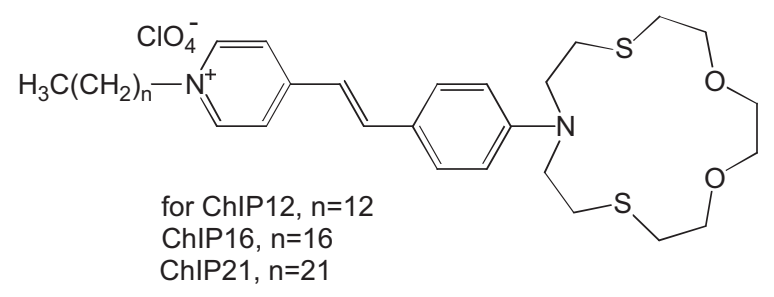

Scheme 1. Chemical structure of the studied amphiphilic dithiaaza-crown substituted chromoionophores.

In the present work we study three dithia-aza-crown-containing hemicyanine dyes with alkyl chain substituents of different lengths (Scheme 1): 4-\{(E)-2-[4-(1,4-dioxa-7,13-dithia-10-azacyclopentadecane-10-yl)-phenyl]vinyl $\}$-1-docosylpyridinium perchlorate (ChIP21), 4-\{(E)-2-[4-(1,4-dioxa-7,13-dithia-10-azacyclopentadecane-10-yl)-phenyl]vinyl $\}-1$-heptadecylpyridinium perchlorate (ChIP16), and 4-\{(E)-2-[4-(1,4-dioxa-7,13-dithia10-azacyclopentadecane-10-yl)-phenyl]vinyl -1-dodecylmethylpyridinium perchlorate (ChIP12). These compounds were synthesized according Scheme 2.

${ }^{1} \mathrm{H}$ and ${ }^{13} \mathrm{C}$ NMR spectra were recorded on Avance 400 device (operational frequency $400 \mathrm{MHz}$ ), internal standard - hexamethyldisiloxane, solvent $-\mathrm{CDCI}_{3}$.

General synthetic procedure for 1-alkyl-4-methylpyridinium perchlorates $(2,3,4)$. Solution of 4-methylpyridine (1) $(0.01$ $\mathrm{mol})$ and corresponding bromide $(0.013 \mathrm{~mol})$ was boiled in $5 \mathrm{~mL}$ of toluene for 10 hours. Obtained reaction mass was transferred into a glass and $30 \mathrm{~mL}$ of diethyl ether was added. Obtained precipitate was filtered and washed with ether, and then dissolved in minimal amount of methyl alcohol, and then added several drops of $65 \%$ aqueous $\mathrm{HCl}$ solution. Beige-coloured precipitate was filtered and then dried.

1-Dodecyl-4-methylpyridinium perchlorate (2). Yield $74 \%$. ${ }^{1} \mathrm{H}$ NMR $\left(\mathrm{CDCI}_{3}\right) \delta_{\mathrm{H}} \mathrm{ppm}: 0.85\left(\mathrm{t}, 3 \mathrm{H}, \mathrm{CH}_{3}\right), 1.22\left(\mathrm{~m}, 20 \mathrm{H}, \mathrm{CH}_{2}\right)$, $1.98\left(\mathrm{t}, 2 \mathrm{H}, \mathrm{CH}_{2}\right), 2.67\left(\mathrm{~s}, 3 \mathrm{H}, \mathrm{CH}_{3}\right), 4.57\left(\mathrm{~m}, 2 \mathrm{H}, \mathrm{CH}_{2}\right), 7.85(\mathrm{~d}, 2 \mathrm{H}$, Py), 8.67 (d, 2H, Py).

1-Hexadecyl-4-methylpyridinium perchlorate (3). Yield $81 \%$. ${ }^{1} \mathrm{H}$ NMR $\left(\mathrm{CDCI}_{3}\right) \delta_{\mathrm{H}} \mathrm{ppm}: 0.87\left(\mathrm{t}, 3 \mathrm{H}, \mathrm{CH}_{3}\right), 1.24\left(\mathrm{~m}, 28 \mathrm{H}, \mathrm{CH}_{2}\right)$, $1.97\left(\mathrm{t}, 2 \mathrm{H}, \mathrm{CH}_{2}\right), 2.67\left(\mathrm{~s}, 3 \mathrm{H}, \mathrm{CH}_{3}\right), 4.60\left(\mathrm{~m}, 2 \mathrm{H}, \mathrm{CH}_{2}\right), 7.83(\mathrm{~d}, 2 \mathrm{H}$, Py), 8.69 (d, 2H, Py).

1-Docosyl-4-methylpyridinium perchlorate (4). Yield $72 \%$. ${ }^{1} \mathrm{H} \mathrm{NMR}\left(\mathrm{CDCI}_{3}\right) \delta_{\mathrm{H}} \mathrm{ppm}: 0.86\left(\mathrm{t}, 3 \mathrm{H}, \mathrm{CH}_{3}\right), 1.23\left(\mathrm{~m}, 38 \mathrm{H}, \mathrm{CH}_{2}\right)$, $1.98\left(\mathrm{t}, 2 \mathrm{H}, \mathrm{CH}_{2}\right), 2.65\left(\mathrm{~s}, 3 \mathrm{H}, \mathrm{CH}_{3}\right), 4.92\left(\mathrm{~m}, 2 \mathrm{H}, \mathrm{CH}_{2}\right), 7.82(\mathrm{~d}, 2 \mathrm{H}$, Py), 8.72 (d, 2H, Py).

General procedure for the preparation of 4-\{(E)-2-[4-(1,4dioxa-7,13-dithia-10-azacyclentenadecan-10-yl)phenyl]ethenyl\}1-alkylmethylpyridinium perchlorates [ChIP12, ChIP16, ChIP21]. A mixture of $0.03 \mathrm{mmol}$ of the corresponding 1-alkyl-4-methylpyridinium perchlorate $(\mathbf{2}, \mathbf{3}, \mathbf{4}), 0.03 \mathrm{mmol}$ of 4-(1,4-dioxa-7,13-dithia- 
<smiles>CCC[n+]1ccc(C)cc1</smiles><smiles></smiles>

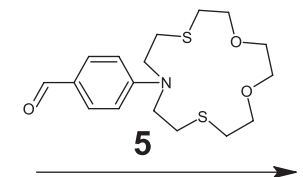

pyrrolidine $\left(\mathrm{CH}_{2}\right)_{\mathrm{n}} \mathrm{CH}_{3}$
$2 \mathrm{n}=12$

butan-1-ol

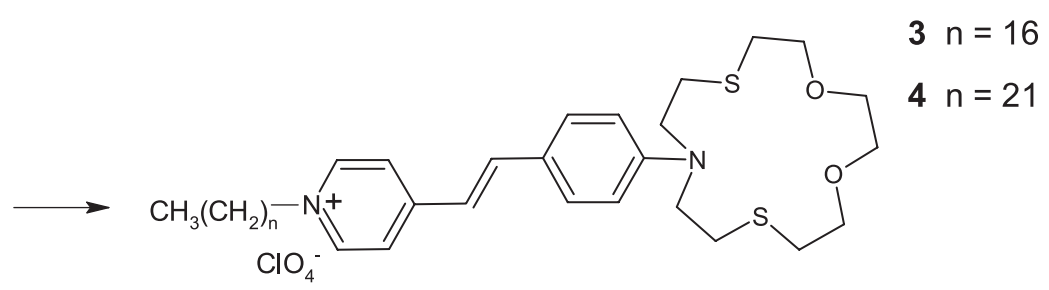

ChIP12, ChIP16, ChIP21

Scheme 2. Synthesis of ChIP12, ChIP16 and ChIP21.

10-azacyclopentadecan-10-yl) benzaldehyde (5), $0.05 \mathrm{~mL}$ of pyrrolidine in $0.5 \mathrm{~mL}$ of $n$-butanol was stirred for 30 minutes at $120^{\circ} \mathrm{C}$. The viscous reaction mass was then evaporated on a rotary evaporator. $10 \mathrm{~mL}$ of methyl alcohol were added to the resulting viscous mass. The resulting red precipitate was filtered, washed with methyl alcohol, and dried.

4-\{(E)-2-[4-(1,4-Dioxa-7,13-dithia-10-azacyclonorodecan10-yl)phenyl]ethenyl\}-1-dodecylmethylpyridinium perchlorate [ChIP12]. Yield $89 \% .{ }^{1} \mathrm{H}$ NMR (d-DMSO) $\delta_{\mathrm{H}}$ ppm: $0.83(\mathrm{t}, 3 \mathrm{H}$, $\left.\mathrm{CH}_{3}\right), 1.22\left(\mathrm{~m}, 20 \mathrm{H}, \mathrm{CH}_{2}\right), 1.86\left(\mathrm{t}, 2 \mathrm{H}, \mathrm{CH}_{2}\right), 2.74-2.82(\mathrm{~m}, 8 \mathrm{H}$, $\left.\mathrm{CH}_{2} \mathrm{~S}\right), 3.57-3.69\left(\mathrm{~m}, 12 \mathrm{H}, \mathrm{CH}_{2} \mathrm{~N}, \mathrm{CH}_{2} \mathrm{O}\right), 4.97(\mathrm{~m}, 2 \mathrm{H}), 6.71(\mathrm{~d}$, $\left.2 \mathrm{H},{ }^{3} J=8.1 \mathrm{~Hz}, \mathrm{Ph}\right), 7.14\left(\mathrm{~d}, 1 \mathrm{H},{ }^{3} J=16.1 \mathrm{~Hz}, \mathrm{CH}=\mathrm{CH}\right), 7.57(\mathrm{~d}$, $\left.2 \mathrm{H},{ }^{3} \mathrm{~J}=8.2 \mathrm{~Hz}, \mathrm{Ph}\right), 7.9\left(\mathrm{~d}, 1 \mathrm{H},{ }^{3} \mathrm{~J}=16.2 \mathrm{~Hz}, \mathrm{CH}=\mathrm{CH}\right), 8.05(\mathrm{~d}, 2 \mathrm{H}$, $\left.{ }^{3} J=6.5 \mathrm{~Hz}, \mathrm{Py}\right), 8.76$ (d, 2H, ${ }^{3} J=6.7 \mathrm{~Hz}$, Py).

4-\{(E)-2-[4-(1,4-Dioxa-7,13-dithia-10-azacyclonorodecan10-yl)phenyl]ethenyl\}-1-hexadecylmethylpyridinium perchlorate [ChIP16]. Yield $77 \%$. ${ }^{1} \mathrm{H}$ NMR $\left(\mathrm{CDCI}_{3}\right) \delta_{\mathrm{H}} \mathrm{ppm}: 0.88(\mathrm{t}, 3 \mathrm{H}$, $\left.\mathrm{CH}_{3}\right), 1.25\left(\mathrm{~m}, 28 \mathrm{H}, \mathrm{CH}_{2}\right), 1.94\left(\mathrm{t}, 2 \mathrm{H}, \mathrm{CH}_{2}\right), 2.78-2.92(\mathrm{~m}, 8 \mathrm{H}$, $\left.\mathrm{CH}_{2} \mathrm{~S}\right), 3.66-3.83\left(\mathrm{~m}, 12 \mathrm{H}, \mathrm{CH}_{2} \mathrm{~N}, \mathrm{CH}_{2} \mathrm{O}\right), 4.42(\mathrm{~m}, 2 \mathrm{H}), 6.66(\mathrm{~d}$, $\left.2 \mathrm{H},{ }^{3} \mathrm{~J}=8.0 \mathrm{~Hz}, \mathrm{Ph}\right), 6.82\left(\mathrm{~d}, 1 \mathrm{H},{ }^{3} \mathrm{~J}=16.0 \mathrm{~Hz}, \mathrm{CH}=\mathrm{CH}\right), 7.50(\mathrm{~d}, 2 \mathrm{H}$, $\left.{ }^{3} \mathrm{~J}=8.2 \mathrm{~Hz}, \mathrm{Ph}\right), 7.50\left(\mathrm{~d}, 1 \mathrm{H},{ }^{3} \mathrm{~J}=16.1 \mathrm{~Hz}, \mathrm{CH}=\mathrm{CH}\right), 7.79(\mathrm{~d}, 2 \mathrm{H}$, $\left.{ }^{3} J=6.5 \mathrm{~Hz}, \mathrm{Py}\right), 8.43$ (d, 2H, $\left.{ }^{3} J=6.6 \mathrm{~Hz}, \mathrm{Py}\right)$.

4-\{(E)-2-[4-(1,4-Dioxa-7,13-dithia-10-azacyclonorodecan-10-yl)phenyl]ethenyl\}-1-docosylmethylpyridinium perchlorate [ChIP21]. Yield $72 \% .{ }^{1} \mathrm{H}$ NMR $\left(\mathrm{CDCI}_{3}\right) \delta_{\mathrm{H}} \mathrm{ppm}: 0.88\left(\mathrm{t}, 3 \mathrm{H}, \mathrm{CH}_{3}\right), 1.25(\mathrm{~m}$, $\left.38 \mathrm{H}, \mathrm{CH}_{2}\right), 1.93\left(\mathrm{~m}, 2 \mathrm{H}, \mathrm{CH}_{2}\right), 2.78-2.91\left(\mathrm{~m}, 8 \mathrm{H}, \mathrm{CH}_{2} \mathrm{~S}\right), 3.66-3.82$ $\left(\mathrm{m}, 12 \mathrm{H}, \mathrm{CH}_{2} \mathrm{~N}, \mathrm{CH}_{2} \mathrm{O}\right), 4.41(\mathrm{~m}, 2 \mathrm{H}), 6.65\left(\mathrm{~d}, 2 \mathrm{H},{ }^{3} \mathrm{~J}=7.8 \mathrm{~Hz}, \mathrm{Ph}\right)$, $6.83\left(\mathrm{~d}, 1 \mathrm{H},{ }^{3} \mathrm{~J}=15.4 \mathrm{~Hz}, \mathrm{CH}=\mathrm{CH}\right), 7.50-7.61(\mathrm{~m}, 3 \mathrm{H}, \mathrm{CH}=\mathrm{CH}, \mathrm{Ph})$, 7.80 (d, 2H, $\left.{ }^{3} \mathrm{~J}=6.7 \mathrm{~Hz}, \mathrm{Py}\right), 8.48$ (d, 2H, $\left.{ }^{3} \mathrm{~J}=6.6 \mathrm{~Hz}, \mathrm{Py}\right)$.

Barium and mercury perchlorates were acquired from SigmaAldrich. Ultrapure water $(18 \mathrm{M} \Omega \mathrm{cm})$ obtained using a Vodolei deionizing apparatus (NPP Khimelektronika) was used for both preparation of aqueous solutions and as a subphase in Langmuir technique experiments.

Langmuir monolayers were formed from $1 \cdot 10^{-4} \mathrm{M}$ chloroform solutions of the studied compounds using a microsyringe according to standard technique. Monolayer compression isotherms were recorded using a KSV mini-trough device (KSV, Finland) equipped with hydrophobic Teflon trough and hydrophilic polyacetal barriers. Monolayer surface pressure was recorded using automated surface pressure balances with a platinum Wilhelmy plate, at a constant temperature of $24 \pm 1{ }^{\circ} \mathrm{C}$.

Absorption spectra of monolayers on aqueous subphase were recorded in the wavelength range of $240-800 \mathrm{~nm}$ using an AvaSpec-2048 optic fiber spectrophotometer equipped with deuterium-halogen light source AvaLight D-HAL (Avantes, Nether- lands). According to the previously described technique, ${ }^{[40]} \mathrm{UV}-\mathrm{Vis}$ reflectometric probe with a fiber diameter of $400 \mu \mathrm{m}$ combined with a six-fiber irradiating cable was located perpendicularly to the subphase surface at a distance of $2-3 \mathrm{~mm}$ from the monolayer. The signal obtained upon light reflection from the subphase surface immediately before the monolayer spreading was used as baseline.

\section{Results and Discussion}

Dithiaaza-crown containing hemicyanine dye with hydrophobic alkyl chain substituents of different length (compounds ChIP12, ChIP16, ChIP21, see Scheme 1) were obtained according to the procedure presented in Scheme 2, which is explained in more detail in the experimental section.

Compounds 2-4 were synthesized according to a standard procedure for the alkylation of 4-methylpyridine (1) with the corresponding alkyl bromides by boiling in toluene followed by the subsequent replacement of the bromide anion with perchlorate anion. The products (ChIP12, ChIP16, ChIP21) were prepared by condensation of the corresponding 1-alkyl-4-methylpyridinium perchlorates $(\mathbf{2}, \mathbf{3}, \mathbf{4})$ with 4-(1,4-dioxa-7,13-dithia-10-azacyclopentadecan-10-yl) with benzaldehyde (5) in $n$-butanol in the presence of pyrrolidine. After this treatment, the desired products (ChIP12, ChIP16, ChIP21) were isolated in individual form and their structure was confirmed by ${ }^{1} \mathrm{H}$ NMR spectra and elemental analysis.

On the first stage of the study of complex formation, we carried out spectrophotometric titration of dithiaaza-crown substituted hemicyanine dyes ChIP12, ChIP16, ChIP21 (Scheme 1) in chloroform solutions by mercury perchlorate dissolved in acetonitrile (Figure 1). It was found that in all cases introduction of mercury cations leads to appearance of a new absorbance band around $350 \mathrm{~nm}$. Binding of mercury cations by crown ether groups of the chromoionophores changes the conjugation length in the molecule chromophore moiety due to interaction of nitrogen atom in ionophoric fragment with the analyte, thus changing the spectral properties. Naturally, increase of mercury perchlorate concentration leads to increase of intensity of this band and decrease of intensity of the absorbance around $500 \mathrm{~nm}$ characteristic 
to unbounded hemicyanine chromoionophore. As was expected, since the chromoionophoric part of all three studied compounds is absolutely identical, all the dyes (ChIP12, ChIP16, and ChIP21) exhibit identical receptor and photophysical properties in solution as the length of alkyl chain substituent (and its presence at all) does not inhibit or promote these kinds of interactions in solution in any way.

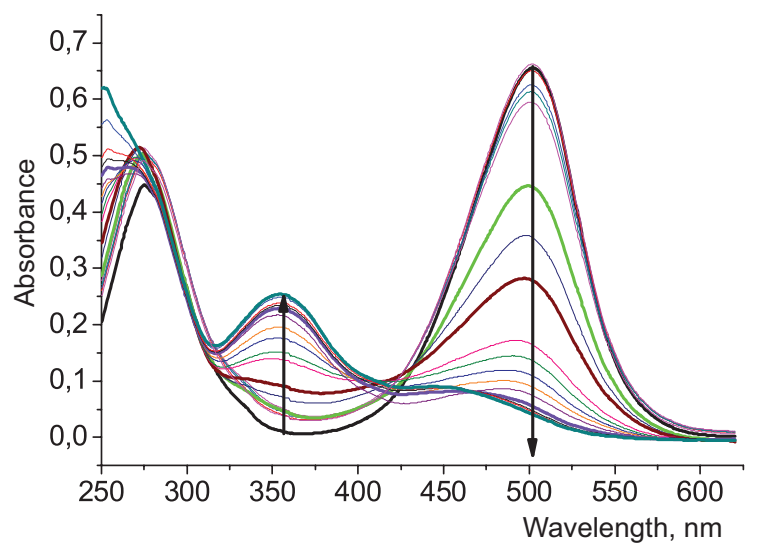

Figure 1. Typical absorbance spectra obtained during spectrophotometric titration of ChIP21 solution in chloroform by mercury perchlorate in range of 0.1 to 5 equivalents.

On the second stage of the present work, we investigated the effect of alkyl chain length on the behaviour of studied hemicyanine chromoionophores in monolayers formed on aqueous subphase according to Langmuir technique. As it can be seen from monolayer compression isotherms (Figure 2) the value of mean molecular area corresponding to beginning of surface pressure growth decreases in the following series: ChIP21 $\rightarrow$ ChIP16 $\rightarrow$ ChIP12, despite the total identity of the hydrophilic chromoionophore parts of these compounds. The shift of these values, apparently, occurs due to different density of the initial structure of the monolayer in liquid-expanded state caused by different long-range hydrophobic chain-to-chain interactions, and lower surface activity of the molecules with shorter alkyl chains, as predicted according to Traube rule. ${ }^{[1]}$

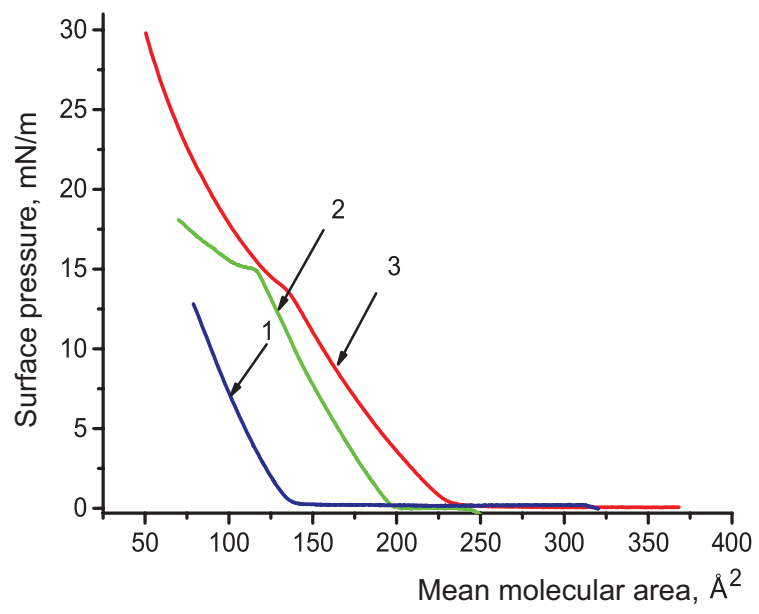

Figure 2. Compression isotherms for ChIP12 (1), ChIP16 (2), and ChIP21 (3) monolayers formed on ultrapure water subphase.
In order to proceed to the investigation of receptor properties of studied monolayer we needed to ensure that mercury cation binding takes place at air/water interface as well. To do so, we formed monolayers of ChIP12, ChIP16, and ChIP21 on the surface of $1 \cdot 10^{-4} \mathrm{M}$ solution of mercury perchlorate and recorded the absorbance spectra. Observed spectra exhibited absorbance peak around $360 \mathrm{~nm}$ for all three cases, thus confirming the possibility of mercury-chromoionophore interaction at the interface. However, from the standpoint of practical application of these systems as sensory platforms, it would be wiser employing not liquidexpanded monolayers, but ones compressed to a significant surface pressure value.

To study the complex formation of the dithiaaza-crown moiety of these compounds with mercury ions in compressed Langmuir monolayers at air/water interface we performed the following experiment. Thus, the monolayers of the studied compounds were formed as usual at ultrapure water surface, compressed until surface pressure value of 10 $\mathrm{mN} / \mathrm{m}$, and then aqueous solution of mercury perchlorate was introduced under such monolayer in different amounts step by step to reach concentration needed. Such experimental conditions allow us to closely model densely packed monolayer before its transfer onto solid substrate, which is interesting from practical standpoint of creation of sensor devices. Spectral response of this system to introduction of mercury into the subphase was recorded in situ by fiber optic spectrometry.

Figure 3 shows typical spectral changes for monolayer of compound ChIP21 upon introduction of different amount of mercury perchlorate under monolayer. It should be noted that for the monolayers of the other two chromophores the spectral response was similar and significant spectral changes are observed only at mercury perchlorate concentration of $5 \cdot 10^{-4} \mathrm{M}$. Apparently, the different density of the initial structure of the monolayer, as dependent on the alkyl chain length, does not significantly affect analyte binding efficiency.

Moreover, as it was shown earlier for the compound analogous to ChIP21, but substituted with azacrown ether group not containing sulfur atoms, "head-to-tail" aggrega-

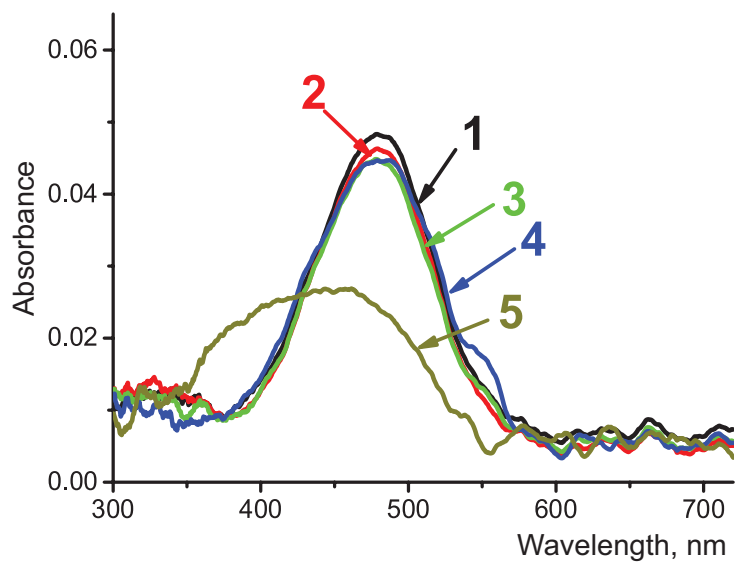

Figure 3. Typical absorbance spectra of ChIP21 monolayer at surface pressure of $10 \mathrm{mN} / \mathrm{m}$ upon introduction of various concentration of $\mathrm{Hg}\left(\mathrm{ClO}_{4}\right)_{2}:$ (1) $1 \cdot 10^{-6}$, (2) $1 \cdot 10^{-5}$, (3) $5 \cdot 10^{-5}$, (4) $10^{-4}$ and (5) $5 \cdot 10^{-4} \mathrm{M}$. 
tion is possible in the monolayers under these conditions. ${ }^{[20]}$ Since chromophoric part of the molecules studied in the present work is completely identical and crown ether moiety differs only by two sulfur atoms, it would be natural to suppose that such aggregation happens in our case as well. Such aggregation inhibits efficient analyte binding due to blocking of the crown-ether moiety by the neighbouring molecule in the aggregate (Scheme 3,a).

To confirm this hypothesis, we carried out the studies of the monolayers formed on the surface of the subphase containing barium cations ( $1 \mathrm{mM}$ barium perchlorate aqueous solution), as it is known from previous study of pure oxygen crown ether substituted hemicyanine monolayers that the presence of such "inert" ions in the subphase inhibits "head-to-tail" aggregation. ${ }^{7,20,33,42]}$

In this case, recorded monolayer compression isotherms (Figure 4) are significantly different to the ones obtained on pure water subphase in overall form and the position of the bend. In addition, more importantly, the value of mean molecular area, at which surface pressure begins to increase, is shifted towards higher values for all three studied compounds. This is especially noticeable for molecules with shorter alkyl chains ChIP12 and ChIP16, in contrast to the case of ChIP21 monolayer, where this change is not as dramatic. Moreover, the difference between these mean molecular area values for all three molecules on barium-containing subphase is much smaller (around $20 \AA^{2}$ ) than in case of pure water subphase ( $60 \AA^{2}$ between ChIP12 and ChIP16, and around $40 \AA^{2}$ between ChIP16 and ChIP21).

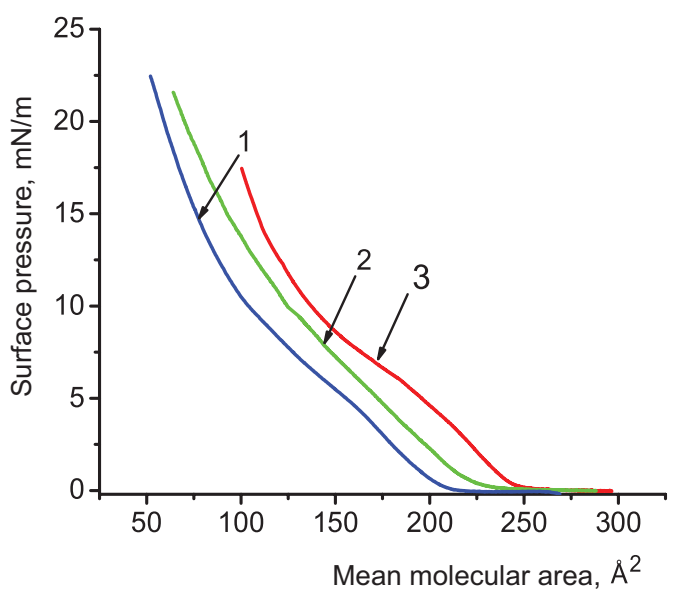

Figure 4. Compression isotherms of (1) ChIP12, (2) ChIP16, and (3) ChIP21 monolayers formed on surface of $1 \mathrm{mM}$ barium perchlorate solution.

Most probably, barium cations preorganize monolayer via weak interaction with dithiaaza-crown ether moiety of the studied molecules in the same way as it was for analogous azacrown substituted hemicyanine dye $\mathrm{e}^{[7,20,33,42]}$ and the resulting repulsion between the likely charged chromoionophoric groups provides the main contribution to the monolayer structure, while the length of alkyl chains are not as important (Scheme 3,b).

At the next step, we studied receptor properties of the pre-compressed monolayers of all three chromoionophores as was described above, but barium perchlorate solu-

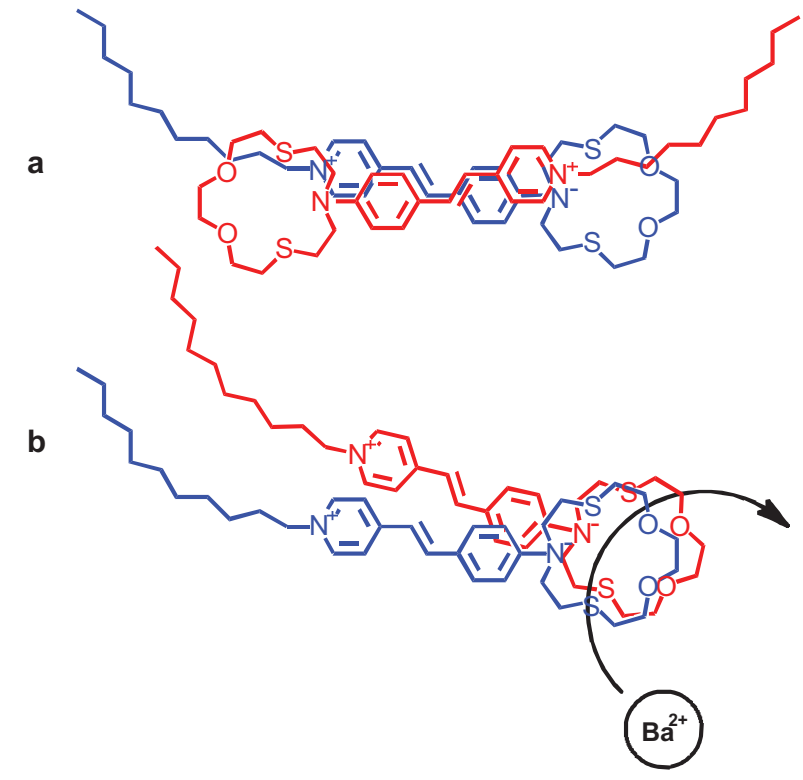

Scheme 3. Schematic representation of the studied hemicyanine dye molecules structure (on example of ChIP12) in (a) the monolayer at pure water subphase in "head-to-tail" aggregated state and (b) in preorganized monolayer at bariumcontaining subphase at the initial stage of monolayer formation.

tion was used as subphase instead of ultrapure water. In this case, monolayers of all three compounds have shown significant change in sensitivity to mercury cations. Spectral responses to the presence of mercury perchlorate in the subphase for all the systems are observed at much lower concentrations than without $\mathrm{Ba}^{2+}$ cations: at $1 \cdot 10^{-6} \mathrm{M}$ in case of ChIP21 monolayer, $1 \cdot 10^{-5} \mathrm{M}$ for ChIP16, and $10^{-4} \mathrm{M}$ for ChIP12. Typical observed spectral changes on example of ChIP21 are shown in Figure 5.

It means that compared to the monolayers formed on pure water, the mercury cation detection limit of the systems preorganized by barium cations is 5 times lower for the case of short alkyl chain length molecule ChIP12, 50

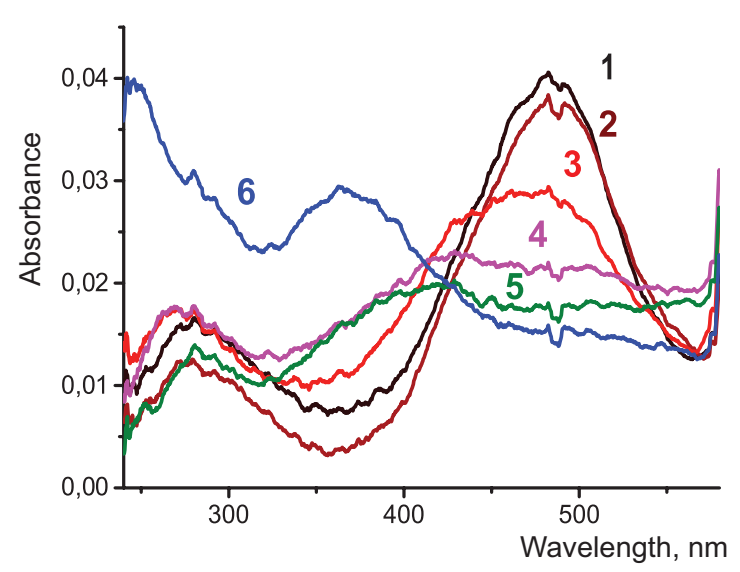

Figure 5. Absorbance spectra of ChIP21 monolayer formed on $1 \mathrm{mM}$ barium perchlorate solution at surface pressure of $10 \mathrm{mN} / \mathrm{m}$ upon introduction of various amounts of $\mathrm{Hg}\left(\mathrm{ClO}_{4}\right)_{2}$ : (1) pure water, (2) $1 \cdot 10^{-7}$, (3) $1 \cdot 10^{-6}$, (4) $1 \cdot 10^{-5}$, (5) $1 \cdot 10^{-4}$, (6) $1 \cdot 10^{-3} \mathrm{M}$. 
times for the case of ChIP16, and 500 times for the case of ChIP21 (Table 1).

Table 1. Detection limits of hemicyanine chromoionophore monolayers to mercury cations in the subphase.

\begin{tabular}{ccc}
\hline & \multicolumn{2}{c}{$\begin{array}{c}\text { Minimum concentration of } \mathrm{Hg}\left(\mathrm{ClO}_{4}\right)_{2} \\
\text { that leads to significant spectral response } \\
\text { of a compressed monolayer }(\mathrm{M})\end{array}$} \\
\hline Compound & $\begin{array}{c}\text { Ultrapure water } \\
\text { subphase }\end{array}$ & $\begin{array}{c}1 \mathrm{mM} \mathrm{Ba}\left(\mathrm{ClO}_{4}\right)_{2} \\
\text { solution subphase }\end{array}$ \\
\hline ChIP21 & $5 \cdot 10^{-4}$ & $1 \cdot 10^{-6}$ \\
ChIP16 & $5 \cdot 10^{-4}$ & $1 \cdot 10^{-5}$ \\
ChIP12 & $5 \cdot 10^{-4}$ & $1 \cdot 10^{-4}$ \\
\hline
\end{tabular}

It should also be noted that introduction of barium perchlorate into the subphase after the compression of the monolayer formed on pure water does not lead to changes of sensitivity of the studied systems in any way. These data agree well with the concepts of preordering mechanism of crown substituted hemicyanine monolayer by inert ions described in. ${ }^{[7]}$ According to this concept, $\mathrm{Ba}^{2+}$ cations weakly interact with crown ether fragments of the chromoionophore at the initial stage of monolayer formation and preorganizes them in monolayer. Apparently, such preorganization occurs while the solvent of precursor solution is still present in the interface, since its evaporation is followed by solvation of both crown ether and barium cation by water molecules which finally leads to formation of monolayer, where hydrophilic crown ether groups of co-ordered hemicyanine fragments are submerged into aqueous phase thus eliminating "head-to-tail" aggregation, where crown ethers are opposite of each other. Probably, the monolayer of the molecules with longer hydrophobic alkyl substituent retains chloroform longer, which gives more time for barium cation induced preorganization at this stage of monolayer formation. On the other hand, molecule with short alkyl chain allows faster release of chloroform from interface, thus decreasing the number of preorganized molecules in the monolayer. This would explain the decrease of the minimum mercury perchlorate concentration required for significant spectral response of monolayers formed at barium-containing subphases with increasing alkyl chain length.

\section{Conclusions}

It is shown that the efficiency of mercury cations binding by monolayer of dithiaaza-crown substituted hemicyanine dyes formed on pure water subphase is identical for all tree compound with various length of alkyl chain substituent $(12,16$, and 21 carbon atoms) due to the key role of the interactions between chromoionophore fragments of neighbouring molecules at the interface. Degree of sensitivity enhancement of the studied systems provided by barium cation induced preorganization increases with increasing alkyl chain length, probably due to effect of longer retention of solvent by longer alkyls in initial stage of monolayer formation, which is a crucial stage for molecular organization at air/water interface.
Acknowledgements. The present work was financially supported by Russian Foundation for Basic Research (grant no. 16-33-60024 - studies of solutions of hemicyanine chromoionophores and ChiP21 monolayers) and Russian Scientific Foundation (project No. 17-73-20268 - all other studies). Experimental studies were performed using equipment of CKP FMI IPCE RAS.

\section{References}

1. Fabbrizzi L., Poggi A. Chem. Soc. Rev. 1995, 24, 197.

2. Kolesnichenko I.V., Anslyn E.V. Chem. Soc. Rev. 2017, 46, 2385-2390.

3. Kim J. Supramolecular Assemblies of Conjugated Sensory Polymers and the Optimization of Transport Properties. Cambridge: MIT Press, 2001. 190 p.

4. Atwood J.L., Davies J.E.D., MacNicol D.D., Vogtle F. Molecular recognition: Receptors for cationic guests. In: Comprehensive Supramolecular Chemistry, Vol. 1. Oxford: Pergamon Press, 1996. p. 635-655.

5. Gromov S.P., Dmitrieva S.N., Vedernikov A.I., Kurchavov N.A., Kuz'mina L.G., Sazonov S.K., Strelenko Y.A., Alfimov M.V., Howard J.A.K., Ushakov E.N. J. Org. Chem. 2013, 78, 9834-9847.

6. Lukovskaya E., Glazova Y., Fedorov Y., Bobylyova A., Mizerev A., Moiseeva A., Anisimov A., Peregudov A., Fedorova O. Dyes Pigm. 2014, 104, 151-159.

7. Selektor S.L., Shcherbina M.A., Bakirov A.V., Batat P., Grauby-Heywang C., Grigorian S., Arslanov V.V., Chvalun S.N. Langmuir 2016, 32, 637-643.

8. Bell T.W., Hext N.M. Chem. Soc. Rev. 2004, 33, 589-598.

9. dos Santos C.M.G., Harte A.J., Quinn S.J., Gunnlaugsson T. Coord. Chem. Rev. 2008, 252, 2512-2527.

10. Kumar A., Sun S.-S., Lees A.J. Coord. Chem. Rev. 2008, 252, 922-939.

11. Selektor S.L., Shokurov A.V. Prot. Met. Phys. Chem. Surfaces 2015, 51, 171-203.

12. Gwon S.-Y., Rao B.A., Kim H.-S., Son Y.-A., Kim S.-H. Spectrochim. Acta, Part A 2015, 144, 226-234.

13. Kuz'mina L.G., Vedernikov A.I., Dmitrieva S.N., Howard J.A.K., Gromov S.P. Russ. Chem. Bull. 2007, 56, 1003-1012.

14. Tsuchiya T., Shimizu T., Hirabayashi K., Kamigata N. J. Org. Chem. 2003, 68, 3480-3485.

15. Bach R.D., Vardhan H.B. J. Org. Chem. 1986, 51, 1609-1610.

16. Lai M.-T., Shih J.-S. Analyst 1986, 111, 891.

17. Li J., Yim D., Jang W.-D., Yoon J. Chem. Soc. Rev. 2017, 46, 2437-2458.

18. Siswanta D., Nagatsuka K., Yamada H., Kumakura K., Hisamoto H., Shichi Y., Toshima K., Suzuki K. Anal. Chem. 1996, 68, 4166-4172.

19. Lochman L., Svec J., Roh J., Novakova V. Dyes Pigm. 2015 $121,178-187$.

20. Batat P., Grauby-Heywang C., Selektor S., Silantyeva D., Arslanov V., McClenaghan N., Jonusauskas G. ChemPhysChem 2014, 15, 2823-2833.

21. Thaler A., Bergter R., Ossowski T., Cox B.G., Schneidera H. Inorg. Chim. Acta 1999, 285, 1-9.

22. Halfpenny J., Rooney P.B., Sloman Z.S. Tetrahedron Lett. 2000, 41, 6223-6226.

23. Bradshaw J.S., Krakowiak K.E., Izatt R.M. The Chemistry of Heterocyclic Compounds, Aza-Crown Macrocycles. John Wiley \& Sons, 2009. 885 p.

24. Berdnikova D.V., Fedorova O.A., Tulyakova E.V., Li H., Kölsch S., Ihmels H. Photochem. Photobiol. 2015, 91, 723731. 
25. Fedorova O.A., Fedorov Y.V., Vedernikov A.I., Yescheulova O.V., Gromov S.P., Alfimov M.V., Kuz'mina L.G., Churakov A.V., Howard J.A.K., Zaitsev S.Y., Sergeeva T.I., Möbius D. New J. Chem. 2002, 26, 543-553.

26. Prodi L., Montalti M., Zaccheroni N., Dolci L. Top. Fluoresc. Spectrosc. 2005, 9, 1-57.

27. Bashmakova N.V., Shaydyuk Y.O., Levchenko S.M., Masunov A.E., Przhonska O.V., Bricks J.L., Kachkovsky O.D., Slominsky Y.L., Piryatinski Y.P., Belfield K.D., Bondar M.V. J. Phys. Chem. A 2014, 118, 4502-4509.

28. Li Y., Wei F., Lu Y., He S., Zhao L., Zeng X. Dyes Pigm. 2013, 96, 424-429.

29. Dix J.P., Voegtle F. Chem. Ber. 1980, 113, 457-470.

30. Shiraishi Y., Miyamoto R., Hirai T. Langmuir 2008, 24, 42734279.

31. Tatay S., Gavi P., Coronado E., Palomares E. Org. Lett. 2006, 8, 3857-3860.

32. Sun W., Guo S., Hu C., Fan J., Peng X. Chem. Rev. 2016, 116, 7768-7817.

33. Shokurov A.V., Silant'yeva D.A., Arslanov V.V., Selektor S.L. Macroheterocycles 2016, 9, 395-401.
34. Caseli L., Moraes M.L., Zucolotto V., Ferreira M., Nobre T.M., Zaniquelli M.E.D., Rodrigues Filho U.P., Oliveira O.N. Langmuir 2006, 22, 8501-8.

35. Apetrei C., Alessio P., Constantino C.J.L., de Saja J.A., Rodriguez-Mendez M.L., Pavinatto F.J., Ramos Fernandes E.G., Zucolotto V., Oliveira O.N. Biosens. Bioelectron. 2011, 26, 2513-2519.

36. Rodriguez-Mendez M.L., de Saja J.A. J. Porphyrins Phthalocyanines 2009, 13, 606-615.

37. Hussain S.-A., Bhattacharjee D. Mod. Phys. Lett. B 2009, 23, 3437-3451.

38. Grauby-Heywang C., Selector S., Abraham E., Jonusauskas G. Prot. Met. Phys. Chem. Surfaces 2011, 47, 31-38.

39. Wang Z., Huang Y., Huang C., Zheng J., Cheng H., Tian S. Synth. Met. 2000, 114, 201-207.

40. Stuchebryukov S.D., Selektor S.L., Silantieva D.A., Shokurov A.V. Prot. Met. Phys. Chem. Surfaces 2013, 49, 189-197.

41. Traube J. Justus Liebig's Ann. Der Chemie 1891, 265, 27-55.

42. Selektor S.L., Raitman O.A., Silant'eva D.A., Ivanova N.V., Yonusauskas G., Lukovskaya E.V., Batat P., Arslanov V.V. Prot. Met. Phys. Chem. Surfaces 2011, 47, 484-493. 